\title{
Anterior Disc Displacement and the Superior Head of Lateral Pterygoid Muscle. A Case-Control Study
}

\author{
Desplazamiento Discal Anterior y la Cabeza Superior del Músculo Pterigoideo Lateral. \\ Un Estudio Caso-Control
}

"Horácio Pompei Filho; **Iván Suazo Galdames; *** Daniela Zavando \& ****Antonio Sergio Guimarães

\begin{abstract}
POMPEI FILHO, H.; SUAZO, G. I.; ZAVANDO, D. \& GUIMARÃES, A. S. Anterior disc displacement and the superior head of lateral pterygoid muscle. A case-control study. Int. J. Morphol., 28(2):365-368, 2010.

SUMMARY: The objective of this study was to assess the association between an increase in the proportion of the superior head of the lateral pterygoid muscle (SHLP) inserted into the temporomandibular joint (TMJ) disc and the presence of anterior disc displacement diagnosed by using MRI. We analyzed 75 images of patients with anterior displacement and 75 controls with normal relationship between the mandibular head and the articular tubercle also diagnosed by MRI. Levels of insertion were measured. Descriptive and analytic statistics were calculated. Analyses of differences were made by Fischer's exact test and also were calculated clinical significance $(\mathrm{OR}, \mathrm{CI}=95 \%)$. The average insertion of SHLP was 71.14\% (SD 14.13) in controls and 67.80\% (SD.16.23) in cases group. The only relationship that presented a significant association (OR 5.61) was found when comparing subjects with a percentage of inserting the disc into the SHLP at $\leq 50 \%$ with those who had higher levels of insertion (50\%). Our results suggest that the highest percentage of insertion serves as a protective factor for anterior disc displacement, probably due to greater control of neuromuscular activity.
\end{abstract}

KEY WORDS: Temporomandibular joint; Lateral pterygoid muscle; Articular disc; Anterior disc displacement.

\section{INTRODUCTION}

The activity of the lateral pterygoid muscle (LPM) is important in the dynamics of the mandibular disc complex (MDC) of the temporomandibular joint (TMJ), especially the superior head of the pterygoid lateral muscle (SHLP), which is inserted into the MCD. The percentage of fibers inserted into the disc from SHLP is still debated in the literature; according to Naohara (1989) the percentages of the total muscle and the superior head are 3 and 30\%, respectively, while for Bittar et al. (1994) the percentage varies between 2.6 and $6 \%$ of total muscle and $31 \%$ of the superior head, which is consistent with that reported by Naidoo \& Juniper (1997) who indicated that $29.5 \%$ of the SHPL fibers are inserted into the disc. Zhang et al. (1998) indicate that only $10 \%$ of these fibers reach the disc, and $24 \%$ reach the joint capsule. The normal activity of the SHPL has been associated with anterior displacement of the disc that occurs with the translation of the jaw opening, and then returns to playing the disc with the mandibular head in the closing oral jaw, because the active relaxation fascicles of the SHPL inserts the disc. Increased muscle activity was associated with anterior dislocation of the disc (Bakke et al., 2005; Taskaya-Yilmaz et al., 2005; Pompei Filho et al., 2009).

Against this background, the purpose of this study is to assess the association between an increase in the proportion of the SHPL disc inserted into the TMJ and the presence of anterior disc displacement diagnosed by using MRI.

\section{MATERIAL AND METHOD}

A case-control study based on a data bank of images from the Center for Computed Tomography of Samaritan Hospital of São Paulo, Brazil, was designed. This study was conducted with the informed consent of patients for the acquisition of the images, and the rules of the ethics

* Dental Research Institute São Leopoldo Mandic, Campinas, Brazil.

** Universidad de Talca, Chile.

**** Universidad Autónoma de Chile, Sede Talca, Chile.

*****Head of TMD Department - Dental Research Institute São Leopoldo Mandic, Campinas, Brazil. 
committee of the Hospital were followed. The examinations were requested by different clinical services for various reasons; images obtained during 2007 were included, excluding those with a history of temporomandibular joint closed-lock, disc adherence, trauma study, or pre- and postTMJ surgery assessment.

Cases. Seventy-five (75) MRI images of TMJ-from 59 women (mean for age 37.3 SD 6.8) and 16 men (mean for age 45.2 SD 6.3), with 41 images of the right side and 34 of the left side-were imagenologically diagnosed with an-

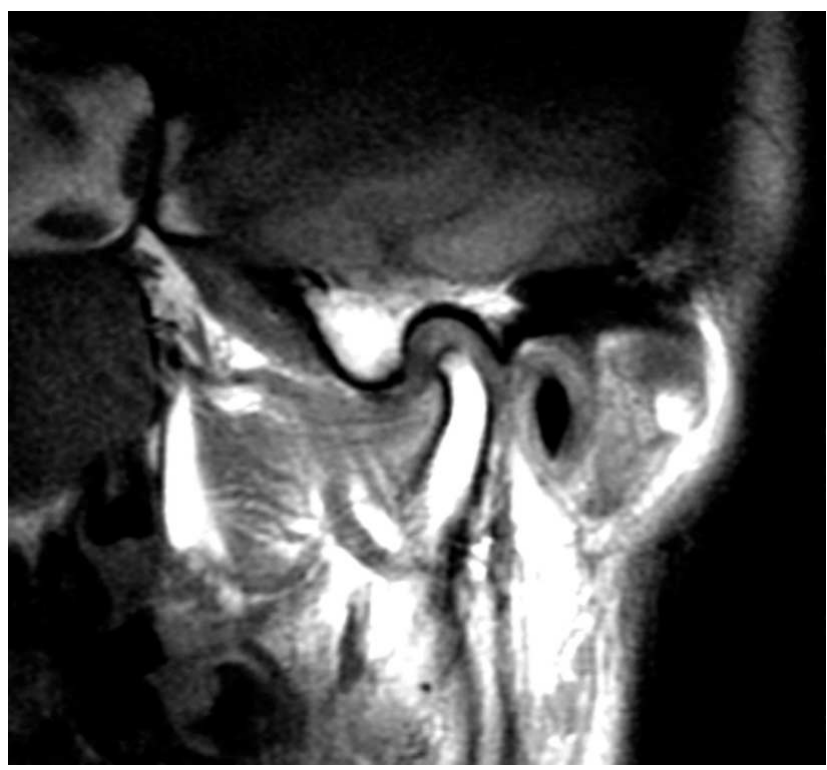

Fig. 1. Sagittal Standard MRI of TMJ at oral closed. Note the anterior disc displacement.

terior disc displacement (Fig. 1).

Controls. Seventy-five (75) MRI images of TMJ-from 54 women (mean for age 39.2 SD 4.5) and 21 men (mean for age 48.6 SD 9.3), with 44 images of the right side and 31 of the left side - with normal relationship between the mandibular head and the articular tubercle were diagnosed. The relationship in which the central and thinner portion of the articular disc is interposed between the mandibular head and the articular tubercle at maximum aperture (Fig. 2) was considered normal.

Images. MRIs of the TMJ were obtained with the patient at maximum aperture without pain, the sagittal standard was corrected, and T1 protocol was used for the anatomical study of the TMJ.

Image analysis. We identified the anatomical components of the joint and delimited the SHLP, disc, and the mandibular head using the software MEVIS 2.9, then

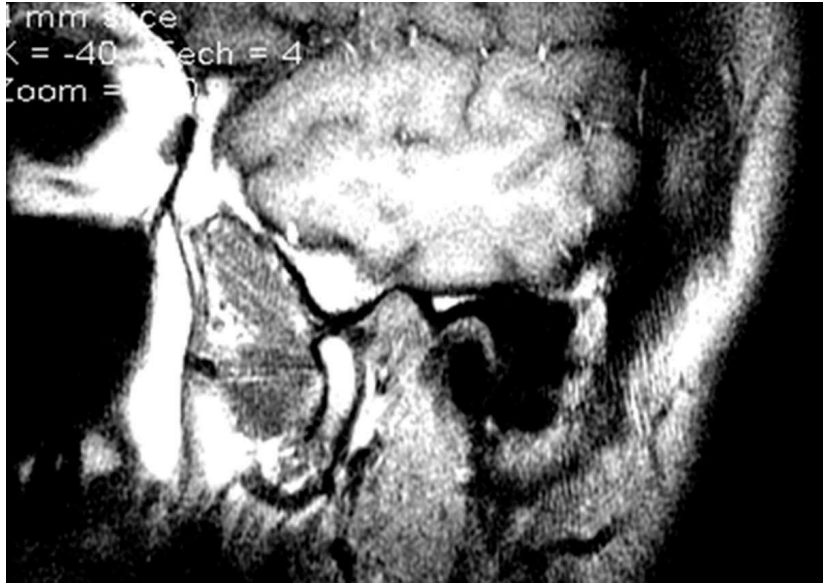

Fig. 2. Sagittal standard MRI of TMJ at maximum aperture without pain. Note the disc interposed between the mandibular head and articular tubercle.

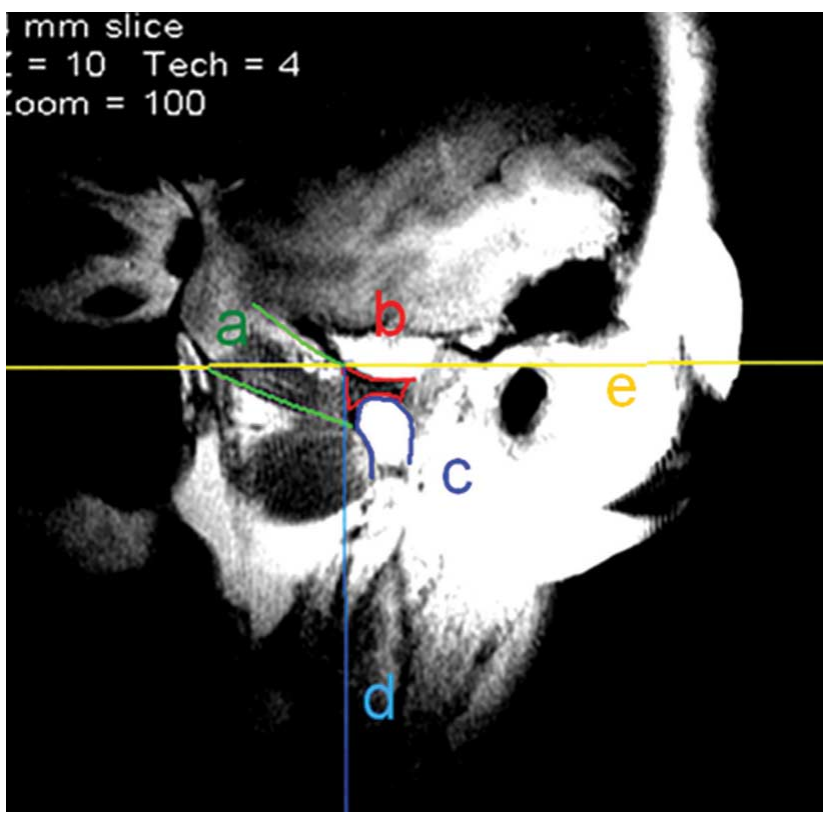

Fig. 3. Standard sagittal MRI image of TMJ. (a) The superior head of the lateral pterygoid muscle was delimited (b) the articular disc $(\mathrm{c}, \mathrm{d}, \mathrm{e})$ the mandibular head and a line perpendicular to the orbitomeatal plane.

measured the linear distance from the end of insertion of the SHLP, and calculated the percentage of SHLP inside the disc; the measurement was made with a guide line perpendicular to the orbitomeatal plane that touched the anterior edge of the disc (Fig. 3).

Reliability. All images had been previously diagnosed by an independent evaluator of the study; they were subjected to an evaluation by a second researcher, who was blind to the initial diagnosis. Only those images in which there was 
agreement between the diagnosis of cases and controls were considered. The reliability of the measurements of the percentage of the SHLP in the disc were analyzed using the remeasurement method of a random sample $(n=15$ cases and $n=15$ controls) and expressed in terms of the correlation coefficient (ICC).

Statistical analysis. Multiple contingency tables' rates for insertion of the SHLP $\leq 50 \% \leq 60 \% \leq 70 \% \leq 80 \% \leq 90 \%$ were built in the presence or absence of anterior disc dislocations. We calculated the odds ratios (OR); Fischer's exact test for the analysis of differences was used, with a $95 \%$ confidence interval.

\section{RESULTS}

The average insertion of SHLP in the disc was $71.14 \%$ (SD 14.13) in the control group subjects and $67.80 \%$ (SD 16.23) in the group with anterior disc displacement with reduction.

The reliability of the measurements was $\mathrm{ICC}=0.85$. The only relationship with a significant association was found when comparing subjects with a $\leq 50 \%$ of inserting the disc into the SHLP to those who had higher levels of insertion (50\%). Detailed results are found in Table I.

Table I. Distribution of cases and controls and statistical association for different insertion levels of SHLP in the disc.

\begin{tabular}{|c|c|c|c|c|c|c|c|}
\hline \multirow{2}{*}{$\begin{array}{c}\text { SHLP insertion in the disc } \\
\leq 50 \%\end{array}$} & \multirow{2}{*}{$\begin{array}{c}\text { Cases } \\
10\end{array}$} & \multirow{2}{*}{$\begin{array}{c}\text { Controls } \\
2\end{array}$} & \multirow{2}{*}{$\begin{array}{c}\mathbf{n} \\
12\end{array}$} & \multirow{2}{*}{$\begin{array}{l}\text { OR } \\
5.61\end{array}$} & \multicolumn{2}{|c|}{$95 \%$ confidence interval } & \multirow{2}{*}{$\begin{array}{c}\text { Fischer's exact test } \\
0.01\end{array}$} \\
\hline & & & & & 1.1248 & 54.0246 & \\
\hline$>50 \%$ & 65 & 73 & 138 & & & & \\
\hline$\leq 60 \%$ & 23 & 20 & 43 & 1.21 & 0.5638 & 2.6328 & 0.35 \\
\hline$>60 \%$ & 52 & 55 & 107 & & & & \\
\hline$\leq 70 \%$ & 48 & 39 & 87 & 164 & 08114 & 3.3275 & 0.09 \\
\hline$>70 \%$ & 27 & 36 & 63 & & & & \\
\hline$\leq 80 \%$ & 60 & 55 & 115 & 1.45 & 0.6348 & 3.3754 & 0.22 \\
\hline$>80 \%$ & 15 & 20 & 35 & & & & \\
\hline$\leq 90 \%$ & 66 & 68 & 134 & 0.75 & 0.2252 & 2.4336 & 0.39 \\
\hline$>90 \%$ & 9 & 7 & 16 & & & & \\
\hline
\end{tabular}

\section{DISCUSSION}

We found an inverse association between the presence of the insertion of the SHLP into the disc and the anterior disc displacement, and we observed a rate of more than $50 \%$ when there was a reduction in the status of disc displacement (OR 5.61); this association was not significant with the other levels of insertion. This result contrasts with the working hypothesis, and that of several authors linking the highest proportion of insertion of SHLP with the highest risk of disc displacement; the mechanical theory for the etiology of the anterior disc displacement with reduction was complemented by neurophysiological theories associating stress with disruption of muscle activation (Desmons et al., 2007), resulting in both disc displacement and hyperactivity of the SHLP.

It is likely that if we only analyze the vectors of force accompanying the activation of motor units of the SHLP, it is reasonable to assume an increase in the percentage of muscle inserted in the disc by its displacement; this assumption underestimates the role of the regulator muscle proprioception and integration that this information has in the mesencephalic trigeminal nucleus. This information, together with significant suprasegmental references receiving trigeminal motor neurons responsible for the contraction of motor units of SHLP, seems to have an important role in regulating disc position. This role is not exclusive, as some authors have described the importance of relations between the components of the TMJ in the disc positions; one example is the low association found in patients with centronuclear myopathy and position changes of the TMJ disc (Zanoteli et al., 2000).

The average percentages of insertion of the SHLP in the disc was much higher than that found in the literature (Zhang et al., 1998); therefore, an analysis of the possible associations in percentages equal to or higher than $50 \%$ in the disc is arguable since the range between the percentages of insertion acts as a protective factor of disk displacement. Hence, larger studies are needed to establish this partnership. 
Our results suggest that the highest percentage of insertion of the SHLP serves as a protective factor for the anterior disc displacement, probably due to greater control of neuromuscular activity.

POMPEI FILHO, H. P.; SUAZO, G. I.; ZAVANDO, D. \& GUIMARÃES, A. S. Desplazamiento discal anterior y la cabeza superior del músculo pterigoideo lateral. Un estudio caso-control. Int. J. Morphol., 28(2):365-368, 2010.

RESUMEN: El objetivo de este estudio fue evaluar la asociación entre el aumento de la proporción de la cabeza superior del músculo pterigoideo lateral (CSPT) insertado en la articulación temporomandibular (ATM) y la presencia de desplazamiento discal anterior diagnosticado mediante resonancia magnética. Se analizaron 75 imágenes de pacientes con desplazamiento discal anterior y 75 controles con una relación normal entre la cabeza de la mandíbula y el tubérculo articular, también diagnosticada por resonancia magnética. Los niveles de inserción fueron medidos. La estadística descriptiva y analítica fueron calculadas. Los análisis de las diferencias se hicieron por la prueba exacta de Fischer, y también se calculó la significancia clínica (OR, IC=95\%). La inserción media de la CSPT fue 71,14\% (DS 14,13) en los controles y 67,80\% (SD 16,23) en los casos de grupo. La única relación que presentó una asociación significativa (OR 5,61) se encontró al comparar los sujetos con un porcentaje de inserción en la CSPT $\leq 50 \%$ con aquellos que tenían niveles más altos de inserción (50\%). Nuestros resultados sugieren que el mayor porcentaje de inserción sirve como un factor de protección para el desplazamiento discal anterior, probablemente debido a un mayor control de la actividad neuromuscular.

PALABRAS CLAVE: Articulación temporomandibular; Músculo pterigoideo lateral; Disco articular; Desplazamiento discal anterior.

\section{REFERENCES}

Bakke, M.; Moller, E.; Werdelin, L. M.; Dalager, T.; Kitai, N. \& Kreiborg, S. Treatment of severe temporomandibular joint clicking with botulinum toxin in the lateral pterygoid muscle in two cases of anterior disc displacement. Oral Surg. Oral Med. Oral Pathol. Oral Radiol. Endod., 100(6):693-700, 2005.

Bittar, G. T.; Bibb, C. A. \& Pullinger, A. G. Histologic characteristics of the lateral pterygoid muscle insertion to the temporomandibular joint. J. Orofac. Pain, 8(3):243-9, 1994.

Desmons, S.; Graux, F.; Atassi, M.; Libersa, P. \& Dupas, P. $\mathrm{H}$. The lateral pterygoid muscle, a heterogeneous unit implicated in temporomandibular disorder: a literature review. Cranio, 25(4):283-91, 2007.

Naohara, H. The macroscopic and microscopic study of the human lateral pterygoid muscle. Tsurumi Shigaku, 15(1):1-26, 1989.

Naidoo, L. C. \& Juniper, R. P. Morphometric analysis of the insertion of the upper head of the lateral pterygoid muscle. Oral Surg. Oral Med. Oral Pathol. Oral Radiol. Endod., 83(4):441-6, 1997.

Pompei Filho, H.; Suazo, G. I. C. \& Guimaraes, A. S. Prevalence of the third head of the lateral pterygoid muscle a magnetic resonance image study. Int. J. Morphol., 27(4):1043-6, 2009.
Taskaya-Yilmaz, N.; Ceylan, G.; Incesu, L. \& Muglali, M. A possible etiology of the internal derangement of the temporomandibular joint based on the MRI observations of the lateral pterygoid muscle. Surg. Radiol. Anat., 27(1):19-24, 2005.

Zanoteli, E.; Guimarães, A. S.; Martins, R. J.; Yamashita, H. K.; Toledo, C. S.; Oliveira, A. S. B. \& Gabbai, A. A. Temporomandibular joint involvement in a patient with centronuclear myopathy. Oral Surg. Oral Med. Oral Pathol. Oral Radiol. Endod., 90(1):118-21, 2000.

Zhang, L.; Sun, L. \& Ma, X. A macroscopic and microscopic study of the relationship between the superior lateral pterygoid muscle and the disk of the temporomandibular joint. Zhonghua Kou Qiang. Yi Xue Za Zhi, 33(5):2679, 1998.

Correspondence to:

Dr. Antonio S. Guimarães

Department - Dental Research Institute Sao Leopoldo Mandic Campinas

Rua Visconde da Luz \#60/31,

São Paulo/SP

BRAZIL.

Received: 22-02-2010

Accepted: 18-03-2010 